\title{
EVALUATION OF CARDIOLIPIN ANTIGEN IN ROUTINE WASSERMANN REACTIONS*
}

\author{
BY \\ SIDNEY SHAW \\ From the Department of Clinical Pathology, Charing Cross Hospital Medical School, London
}

Cardiolipin is a phospholipid and was isolated by Pangborn (1941, 1942) while investigating the nature of the antigenic material in beef heart muscle used in the Wassermann reaction. It was shown that cardiolipin was serologically active when used together with lecithin, and that the sensitivity of the reaction was enhanced by the addition of cholesterol. A monograph on cardiolipin antigen was published by Pangborn and others (1951), and details of this antigen and methods of preparation are given.

Many publications discuss the value of cardiolipin antigen in complement-fixation tests (CFT) and flocculation tests, and most workers have made a strong case for the adoption of this antigen in order to obtain greater sensitivity and specificity in these tests. Mazzini (1951) describes a microflocculation cardiolipin test, and writes that a vast improvement in sero-diagnostic procedures has been made with this antigen, but that there is a tendency to zonal reactions. Lundbäck and Allander (1951) point out that cardiolipin-lecithin-cholesterol antigen is superior to the old crude extract with regard to specificity and probably to sensitivity as well. Vogelsang and Haaland (1951) also note that cardiolipin antigen is more specific and offers certain advantages when applied to complementfixation and flocculation tests. The following published reports are also in favour of cardiolipin antigens, particularly with regard to increased specificity and sensitivity : Chronicle of the World Health Organization (1951), Joulia and Pautrizel (1951a, b), Flynn, Tompkins, and Beecher (1952), and Steigner (1954). Guthe and Willcox (1954) write, " the more specific cardiolipin antigens have now been accepted everywhere as the antigens of choice in the sero-diagnosis of syphilis ". Rappaport and Eichhorn (1951) used a tube flocculation method with three different formulae for the cardiolipin antigen and obtained practically identical results in specificity and sensitivity. Giordano, Shively, and Bahler (1952) compared cardiolipin

\footnotetext{
* Received for publication December 8, 1954
}

microflocculation VDRL (American) antigen with standard Kolmer CFT antigen used in the Kolmer complement-fixation test, and found that the cardiolipin antigen gave increased sensitivity, but slight loss in specificity. They advised cardiolipin antigen for routine use. Price and Wilkinson (1950) reviewed the results of over 5,000 complementfixation tests using cardiolipin and standard antigen (1/15 dilution) in parallel tests. With sera from a V.D. clinic and with routine hospital patients, cardiolipin gave increased sensitivity, but more non-specific results. The same authors (1952) again compared a large series using the standard antigen at optimum titre with similar results. Nelson and Martin (1954), Klein, Konwaler, and Leiby (1954), and Price (1954) have independently compared complement-fixation tests with standard and cardiolipin antigens, and recorded increased sensitivity but loss of specificity with cardiolipin.

Tests at the London Lock and Charing Cross Hospitals

Dr. Fawkner-Corbett of the London Lock Hospital commenced parallel testing with cardiolipin and crude heart antigens in March, 1952. When the V.D. centre closed down late that year, he very kindly passed his records to the author.

At the Charing Cross Hospital similar parallel testing of sera was commenced in January, 1953, using the same technique as that used at the Lock Hospital. The author was also fortunate in securing the services of Dr. Fawkner-Corbett's serological technician. The standard antigen was used as in Harrison and Wyler's technique at a dilution of $1 / 15$ in saline ; the cardiolipin antigen was made up in accordance with the Burroughs Wellcome Whitechapel formula, and so far each batch has been used at the recommended dilution of 1 in $\mathbf{4 0 0}$. There are obvious physical differences in these antigens at these strengths; the cardiolipin is only very faintly opalescent and during the complement titration is little more destructive of complement than saline.

Results.-A total of 7,337 sera were compared and the results subdivided into eight groups :

(1) Altogether 2,773 sera were compared at the London Lock Hospital. The subdivision of the results show that those in disagreement were mainly borderline results; cardiolipin antigen gave results 3.5 per cent. 
greater than standard antigen, and vice versa in only 0.4 per cent. (Table I).

\section{TABLE I}

LONDON LOCK HOSPITAL SERA

(March 7 to October 31, 1952)

\begin{tabular}{|c|c|c|c|}
\hline \multicolumn{2}{|c|}{ Results } & \multirow{2}{*}{$\begin{array}{c}\begin{array}{c}\text { Number of } \\
\text { Sera }\end{array} \\
125 \\
55 \\
2,486\end{array}$} & \multirow{2}{*}{$\begin{array}{c}\text { Per cent. } \\
96 \cdot 1\end{array}$} \\
\hline $\begin{array}{l}\text { Titres } \\
\text { Agree }\end{array}$ & $\begin{array}{l}\text { Both }+ \\
\text { Both } \pm \\
\text { Both }-\end{array}$ & & \\
\hline \multirow{2}{*}{$\begin{array}{c}\text { Titres } \\
\text { Disagree }\end{array}$} & $\begin{array}{l}\mathbf{C}+\mathbf{S}- \\
\mathrm{C} \pm \mathbf{S}- \\
\mathbf{C}+\mathbf{S} \pm\end{array}$ & $\begin{array}{r}5 \\
61 \\
31\end{array}$ & $\underset{3.5}{\mathrm{C}_{2}>\mathrm{S}}$ \\
\hline & $\begin{array}{l}\mathbf{S}+\mathbf{C}- \\
\mathbf{S} \pm \mathbf{C}- \\
\mathbf{S}+\mathbf{C} \pm\end{array}$ & $\begin{array}{c}\text { nil } \\
10 \\
\text { nil }\end{array}$ & $\underset{0.4}{S}>C$ \\
\hline \multicolumn{2}{|c|}{ Total tested } & 2,773 & 100 \\
\hline
\end{tabular}

$\mathbf{C}=$ Cardiolipin antigen, $\mathbf{S}=$ Standard antigen $;+=$ positive, $\pm=$ weakly positive, $-=$ negative.

(2) Sera that were positive at 1 in 10 dilution with either antigen and were quantitatively titrated are compared in Table II. With the majority of positives cardiolipin gave a higher titre than standard; the difference in titre was usually one tube. This Table, therefore, shows increased sensitivity of cardiolipin antigen with positive tests.

\section{TABLE II}

LONDON LOCK HOSPITAL SERA

Comparison of Titres Positive at 1 in 10 or More with Cardiolipin or Standard Antigen from 2,773 Sera Tested

\begin{tabular}{|c|c|c|}
\hline Results & Number of Sera & Per cent. \\
\hline Agree & 41 & $22 \cdot 7$ \\
\hline $\mathrm{C}>\mathrm{S}$ & 119 & $65 \cdot 7$ \\
\hline$S>C$ & 21 & $11 \cdot 6$ \\
\hline Total & 181 & 100 \\
\hline
\end{tabular}

(3) Table III shows a comparison of the results of tests on sera from 74 new cases of syphilis which gave a positive or weakly positive result with either antigen. (Some of these sera were referred from elsewhere, but others were genuine cases of early syphilis.) Cardiolipin antigen appears to be more sensitive with new cases.

TABLE III

LONDON LOCK HOSPITAL SERA

74 New Cases of Syphilis Positive with Cardiolipin or Standard Antigen

\begin{tabular}{|c|c|c|c|c|}
\hline \multicolumn{2}{|c|}{ Results } & $\begin{array}{c}\text { Number of } \\
\text { Sera }\end{array}$ & & Total \\
\hline Agree & $\begin{array}{l}\text { Both + } \\
\text { Both }=\end{array}$ & $\begin{array}{l}36 \\
16\end{array}$ & \} & 52 \\
\hline \multirow{2}{*}{ Disagree } & $\begin{array}{l}\mathbf{C}+\mathbf{S}- \\
\mathbf{C}=\mathbf{S}- \\
\mathbf{C}+\mathbf{S} \pm\end{array}$ & $\begin{array}{r}2 \\
14 \\
5\end{array}$ & \} & $\underset{21}{C}>S$ \\
\hline & $\begin{array}{l}\mathbf{S}+\mathbf{c}- \\
\mathbf{S}=\mathbf{c}- \\
\mathbf{s}+\mathbf{C} \pm\end{array}$ & $\begin{array}{c}\text { nil } \\
1 \\
\text { nil }\end{array}$ & \} & $\underset{1}{S_{1}} \mathbf{C}$ \\
\hline \multicolumn{2}{|c|}{ Total sera } & 74 & & 74 \\
\hline
\end{tabular}

(4) A similar comparison is shown in Table IV with old treated cases; cardiolipin antigen was more sensitive.

TABLE IV

LONDON LOCK HOSPITAL SERA

213 Old Treated Cases of Syphilis Positive with Cardiolipin or Standard Antigen

\begin{tabular}{|c|c|c|c|}
\hline \multicolumn{2}{|c|}{ Results } & $\underset{\text { Sera }}{\text { Number of }}$ & Total \\
\hline Agree & $\begin{array}{l}\text { Both }+ \\
\text { Both } \pm\end{array}$ & $\begin{array}{l}89 \\
39\end{array}$ & \} 128 \\
\hline \multirow{2}{*}{ Disagree } & $\begin{array}{l}\mathbf{C}+\mathbf{S}- \\
\mathbf{C} \pm \mathbf{S}- \\
\mathbf{C}+\mathbf{S} \pm\end{array}$ & $\begin{array}{r}3 \\
47 \\
26\end{array}$ & $\begin{array}{l}C>S \\
76\end{array}$ \\
\hline & $\begin{array}{l}\mathbf{S}+\mathbf{C}- \\
\mathbf{S} \pm \mathbf{C}- \\
\mathbf{S}+\mathbf{C} \pm\end{array}$ & $\begin{array}{r}\text { nil } \\
9 \\
\text { nil }\end{array}$ & $\mathrm{S}>\mathrm{C}$ \\
\hline \multicolumn{2}{|c|}{ Total sera } & 213 & 213 \\
\hline
\end{tabular}

(5) Table $V$ shows a comparison of 1,792 sera from routine patients at the Charing Cross Hospital, excluding antenatal sera.

TABLE V

CHARING CROSS HOSPITAL SERA

Comparison of 1,792, excluding Antenatal, Sera (January 1, 1953 to June 6, 1954)

\begin{tabular}{|c|c|c|c|}
\hline \multicolumn{2}{|c|}{ Results } & $\begin{array}{c}\text { Number of } \\
\text { Sera }\end{array}$ & Per cent. \\
\hline Agree & $\begin{array}{l}\text { Both }+ \\
\text { Both } \pm \\
\text { Both - }\end{array}$ & $\begin{array}{r}66 \\
34 \\
1,650\end{array}$ & $97 \cdot 7$ \\
\hline \multirow{2}{*}{ Disagree } & $\begin{array}{l}\mathbf{C}+\mathbf{S}- \\
\mathbf{C} \pm \mathbf{S}- \\
\mathbf{C}+\mathbf{S}_{ \pm}\end{array}$ & $\begin{array}{r}7 \\
19 \\
9\end{array}$ & $\begin{array}{l}\mathrm{C}>\mathrm{S} \\
1.9\end{array}$ \\
\hline & $\begin{array}{l}\mathbf{S}+\mathbf{C}- \\
\mathbf{S} \pm \mathbf{C}- \\
\mathbf{S}+\mathbf{C} \pm\end{array}$ & $\begin{array}{l}2 \\
2 \\
3\end{array}$ & $\underset{0.4}{S>C}$ \\
\hline \multicolumn{2}{|c|}{ Total tested } & 1,792 & 100 \\
\hline
\end{tabular}

(6) From the 1,792 sera in Table $V$ there were 111 known cases of syphilis, many being old treated ones, at the Charing Cross Hospital. A comparison is made in Table VI of these sera which gave a positive or doubtful result with either antigen; there was again an increased

TABLE VI

CHARING CROSS HOSPITAL SERA

Comparison of 111 known Cases of Syphilis, excluding Antenatal, Positive with Cardiolipin or Standard Antigen

\begin{tabular}{|c|c|c|c|}
\hline \multicolumn{2}{|c|}{ Results } & $\begin{array}{c}\text { Number of } \\
\text { Sera }\end{array}$ & Totals \\
\hline Agree & $\begin{array}{l}\text { Both }+ \\
\text { Both } \pm\end{array}$ & $\begin{array}{l}65 \\
* 18\end{array}$ & 83 \\
\hline \multirow{2}{*}{ Disagree } & $\begin{array}{l}\mathbf{C}+\mathbf{S}- \\
\mathbf{C} \pm \mathbf{S}_{ \pm} \\
\mathbf{C}+\mathbf{S}_{ \pm}\end{array}$ & $\begin{array}{r}* 4 \\
* 15 \\
* 5\end{array}$ & $\underset{24}{\mathrm{C}>\mathrm{S}}$ \\
\hline & $\begin{array}{l}\mathbf{S}+\mathbf{C}- \\
\mathbf{S} \pm \mathbf{C}- \\
\mathbf{S}+\mathbf{C} \pm\end{array}$ & $\begin{array}{l}* 1 \\
\text { nil } \\
* 3\end{array}$ & $S>C C$ \\
\hline \multicolumn{2}{|c|}{ Total sera } & 111 & 111 \\
\hline
\end{tabular}

*Nearly all old treated cases. 
sensitivity of cardiolipin antigen with old treated cases as was shown with those of the London Lock Hospital (Table IV).

(7) From the 1,792 sera in Table V, 22 gave results considered as non-specific reactions (Table VII). No history of syphilis was obtained, the Kahn tests were all negative and many of these complement-fixation tests were repeated with similar or negative results (two of these sera were from cases of glandular fever and one from a case of disseminated lupus erythematosus). It will be seen that cardiolipin antigen gave more nonspecific reactions with these routine hospital sera.

\section{TABLE VII}

CHARING CROSS HOSPITAL SERA

22 Cases considered as Non-Specific Reactions

\begin{tabular}{|c|c|c|}
\hline \multicolumn{2}{|c|}{ Results } & Number of Sera \\
\hline Agree & Both \pm & 12 \\
\hline \multirow{2}{*}{ Disagree } & $\begin{array}{l}\mathbf{C}+\mathbf{S}- \\
\mathbf{C} \pm \mathbf{S}= \\
\mathbf{C}+\mathbf{S} \pm\end{array}$ & $\begin{array}{l}2 \\
3 \\
3\end{array}$ \\
\hline & $\begin{array}{l}\mathbf{S}+\mathbf{C}- \\
\mathbf{S} \pm \mathbf{C}- \\
\mathbf{S}+\mathbf{C} \pm\end{array}$ & $\begin{array}{r}1 \\
1 \\
\text { nil }\end{array}$ \\
\hline Total (non-specific) & $\ldots$ & 22 \\
\hline
\end{tabular}

(8) Table VIII shows a comparison of 2,772 antenatal sera tested during the same period at the Charing Cross Hospital. A very high incidence of doubtful results is seen with cardiolipin antigen. Many of the doubtful results were repeated with the same or negative result and with negative Kahn tests and were considered as non-specific reactions.

TABLE VIII

CHARING CROSS HOSPITAL SERA

2,772 Antenatal Sera tested from January 1, 1953, to June 9, 1954

\begin{tabular}{|c|c|c|c|}
\hline \multicolumn{2}{|c|}{ Results } & $\begin{array}{c}\text { Number of } \\
\text { Sera }\end{array}$ & Per cent. \\
\hline Agree & $\begin{array}{l}\text { Both }+ \\
\text { Both } \pm \\
\text { Both- }\end{array}$ & $\begin{array}{r}5 \\
* 33 \\
2,633\end{array}$ & $96 \cdot 3$ \\
\hline \multirow{2}{*}{ Disagree } & $\begin{array}{l}\mathbf{C}+\mathbf{S}- \\
\mathbf{C} \pm \mathbf{S}= \\
\mathbf{C}+\mathbf{S} \pm\end{array}$ & $\begin{array}{l}* 21 \\
* 67 \\
* 6\end{array}$ & $\underset{3.4}{C>S}$ \\
\hline & $\begin{array}{l}\mathbf{S}+\mathbf{C}- \\
\mathbf{S} \pm \mathbf{C}- \\
\mathbf{S}+\mathbf{C} \pm\end{array}$ & $\begin{array}{c}\text { nil } \\
* 7 \\
\text { nil }\end{array}$ & $\underset{0.3}{S>C}$ \\
\hline \multicolumn{2}{|c|}{ Total tested } & 2,772 & 100 \\
\hline
\end{tabular}

* Many repeated with same or negative result.

\section{Conclusions}

From the above Tables showing the results of parallel complement-fixation tests, it may be con- sidered that cardiolipin is undoubtedly a more sensitive antigen with treated cases of syphilis, and is apparently more sensitive with early cases.

The increase in non-specific reactions, which was particularly marked with antenatal sera, is a serious disadvantage. A further possible disadvantage is that the test usually remains positive after the standard antigen test has become negative in treated cases.

With antenatal sera a doubtful cardiolipin result is no longer reported when the standard Wassermann and Kahn tests are both negative.

It is very likely that with modification in formula and technique this antigen may become more specific in use and will then have a greater practical value.

\section{Summary}

An assessment of the value of cardiolipin antigen compared with standard antigen in over 7,000 complement-fixation tests is made. Cardiolipin gave increased sensitivity but loss of specificity; non-specific reactions were particularly evident with antenatal sera.

I wish to thank Miss G. Pierpoint for valuable technical assistance, and also my secretary Miss G. Rayner.

\section{REFERENCES}

Chron. Wld Hlth Org. (1951). 5, 265.

Flynn, M. R., Tompkins, V., and Beecher, T. (1952). Amer. J. Syph., 36, 272.

Giordano, A. S., Shively, J. A., and Bahler, J. W. (1952). Amer. J. clin. Path., 22, 285.

Guthe, T., and Willcox, R. R., (1954). "Treponematoses." Reprinted from Chron. Wld Hith Org., 8, 37.

Joulia, P., and Pautrizel, R. (1951a). Bull. Soc. franc. Derm. Syph., $58,242$.

- - (1951b). Ibid., 58, 243.

Klein, S. J., Konwaler, B. E., and Leiby, G. M. (1954). Amer. J. Syph., 38, 318.

Lundbäck, H., and Allander, A. L. (1951). Acta path. microbiol. scand., 29, 287.

Mazzini, L. Y. (1951). J. Immunol., 66, 261.

Nelson, M. G., and Martin, E. P. (1954). Irish J. med. Sci., 6th series, no. 341 , p. 218.

Pangborn, M. C. (1941). Proc. Soc. exp. Biol. (N.Y.), 48, 484.

(1942). J. biol. Chem., 143, 247.

-, Maltaner, F., Tompkins, V. N., Beecher, T., Thompson, W. R., and Flynn, M. R. (1951). Bull. Wld Hlth Org., 4, 151.

Price, I. N. O. (1954). British Journal of Venereal Diseases, 30, 210. -, and Wilkinson, A. E. (1950). Lancet, 1, 14.

- - (1952). British Journal of Venereal Diseases, 28, 16.

Rappaport, F., and Eichhorn, F. (1951). Acta med. orient.(Tel-Aviv), $10,200$.

Steigner, K. F. (1954). Zent. Bakt. I. Abt. Orig., 161, 69.

Vogelsang, T. M., and Haaland, R. (1951). British Journal of Venereal Diseases, $27,52$. 